This document was prepared in conjunction with work accomplished under Contract No. DE-AC09-96SR18500 with the U.S. Department of Energy.

This work was prepared under an agreement with and funded by the U.S. Government. Neither the U. S. Government or its employees, nor any of its contractors, subcontractors or their employees, makes any express or implied: 1 . warranty or assumes any legal liability for the accuracy, completeness, or for the use or results of such use of any information, product, or process disclosed; or 2 . representation that such use or results of such use would not infringe privately owned rights; or 3 . endorsement or recommendation of any specifically identified commercial product, process, or service. Any views and opinions of authors expressed in this work do not necessarily state or reflect those of the United States Government, or its contractors, or subcontractors. 


\title{
Interactions among phosphate amendments, microbes and uranium mobility in contaminated sediments
}

\author{
Anna Sophia Knox ${ }^{a}$, R.L. Brigmon, D.I. Kaplan, and M.H. Paller \\ Savannah River National Laboratory, Aiken, SC 29808, USA \\ ${ }^{a}$ Corresponding author: A.S. Knox, 803-725-7021 (phone), 803-725-7673 (fax), \\ anna.knox@srnl.doe.gov, Building 773-42A, Savannah River Site, Aiken, SC 29808
}

\begin{abstract}
The use of sequestering agents for the transformation of radionuclides in low concentrations in contaminated soils/sediments offers considerable potential for longterm environmental cleanup. This study evaluated the influence of four phosphate amendments and two microbial amendments on $\mathrm{U}$ availability. The synchrotron X-ray fluorescence mapping of the untreated U-contaminated sediment showed that U was closely associated with Mn. All tested phosphate amendments reduced aqueous U concentration more than $90 \%$, likely due to formation of insoluble phosphate precipitates. The addition of $A$. piechaudii and $P$. putida alone were found to reduce $U$ concentrations $63 \%$ and $31 \%$ respectively. Uranium sorption in phosphate treatments was significantly reduced in the presence of microbes. However, increased microbial activity in the treated sediment led to reduction of phosphate effectiveness. The average $\mathrm{U}$ concentration in $1 M$ $\mathrm{MgCl}_{2}$ extract from $\mathrm{U}$ amended sediment was $437 \mu \mathrm{g} / \mathrm{kg}$, but in the same sediment without microbes (autoclaved sediment), the extractable U concentration was only 103 $\mu \mathrm{g} / \mathrm{kg}$. When the autoclaved amended sediment was treated with autoclaved biological apatite, $\mathrm{U}$ concentration in the $1 \mathrm{M} \mathrm{MgCl}_{2}$ extract was $\sim 0 \mu \mathrm{g} / \mathrm{kg}$. Together these tests
\end{abstract}


suggest that microbes may enhance $U$ leaching and reduce phosphate amendment remedial effectiveness.

Keywords: Apatite, Uranium, Microbial activity, A. piechaudii, and P. putida

\section{Introduction}

Activities associated with the mining and processing of uranium (U) ores as well as defense-related activities have resulted in vast areas of contaminated sediments and groundwater. Uranium is a significant contaminant on the Savannah River Site (SRS) in Aiken, South Carolina and at several other Department of Energy sites. Radionuclides that contaminate water, sediments, or sediments cannot be destroyed, but the toxicity of these inorganic contaminants can be diminished through alteration of their chemical speciation. Ideally, such chemical alterations (e.g., reduction or precipitation) will convert toxic and mobile species to nontoxic and immobile species. The use of phosphate sequestering agents for the transformation of radionuclides in low concentrations in contaminated sediments offers considerable potential for long-term environmental cleanup. However, there are several number of bacterial species (Alcaligenes, Acinetobacter, Arthrobacter, Azospirillum, Bacillus, Pseudomonas, Rhizobium,and others) that are able to solubilize phosphate minerals (Rodriguez et al., 1999) and therefore, could enhance or inhibit in-situ remediation of $U$ with phosphate amendments. The principal mechanism for mineral phosphate solubilization by bacteria is the production of organic acids. It is generally accepted that the major mechanism of mineral phosphate solubilization is the action of organic acids synthesized by soil 
microorganisms. Production of organic acids results in acidification of the microbial surroundings.

Phosphates such as apatite $\left(\mathrm{Ca}_{5}\left(\mathrm{PO}_{4}\right)_{3} \mathrm{OH}\right)$, are common surface and subsurface amendments (Knox et al., 2004) that effectively immobilizes $\mathrm{Pb}$ and other constituents (e.g., Cd, Ni, Zn, and U) in contaminated soils/sediments (Knox, et al, 2000 a, b; Knox et al., 2003 and 2004; Ma et al., 1995, 1997; Singh et al., 2001), thus offering an economical, simple, and environmentally friendly alternative to treat contaminated environments. Properly selected phosphate amendments mixed in contaminated sediment or soils can effectively reduce metal mobility, bioavailability, and toxicity. Rock phosphates and biological apatite, such as fish bones, have been used at several contaminated remediation sites (Knox, et al., 2004). Biological apatite is relatively very soluble, making it immediately available for interaction with contaminated soils/sediments. Biological apatite also has much lower concentrations of impurities (As, $\mathrm{Cr}$, and $\mathrm{U}$ ) that may potentially leach into the surrounding groundwater (Knox, et al., 2004; Knox et al., 2006b).

Calcium phytate removes contaminants in the same manner as apatite minerals. Recent studies have suggested that phytate can be applied in a soluble form for delivery to remote contaminated sediments, where it undergoes various reactions that eventually result in the precipitation of the contaminant metals (Jensen et al., 1996; Nash et al., 1997, 1998 a, b). Metal interactions with calcium phytate can lead to both intra-and intermolecular bonding resulting in the simultaneous formation of numerous monomeric and polymeric species, which can lead to the coprecipitation of nonstochiometric solidphase mixtures as the metal to ligand ratio increases (Wise, 1986). Naturally occurring 
metal ions like $\mathrm{Ca}^{2+}$ have been demonstrated to have a positive influence on metal ionexchange and mineralization in the presence of phytate (Nash et al., 1997). Contaminant metals may be coprecipitated or exchanged with $\mathrm{Ca}$ in Ca phytate at concentrations that are insufficient to promote precipitation by themselves (Wise, 1986). Additionally, metals such as $\mathrm{Pb}$ may be strongly sorbed to precipitated Ca phytate without resulting in the stochiometric release of $\mathrm{Ca}^{2+}$ (Wise, 1986). Although coprecipitation or metal exchange with Ca phytate may initially reduce contaminant metal solubility, Nash and coworkers (Jensen et al., 1996; Nash et al., 1997, 1998a, b) suggest Ca phytate hydrolysis and mineralization release inorganic $\mathrm{PO}_{4}$, which can result in further contaminant immobilization through the formation of insoluble secondary contaminant-phosphate precipitates in a manner similar to the addition of apatite or hydroxyapatite (HA) to metal contaminated sediment/soil.

The objective of this paper was to evaluate phosphate amendments for the cost effective remediation of $\mathrm{U}$ - contaminated soil/sediments and to identify phosphate /microbial interaction that could affect remediation effectiveness.

\section{Materials and methods}

\subsection{Phosphate and microbial amendments}

Three types of phosphate (rock phosphate, biological phosphate, and chemical reagent -calcium and sodium phytate) and two microbial amendments (Alcaligenes piechaudii and Pseudomonas putida) were tested. Alcaligenes pechaudii was isolated from petroleum hydrocarbon-contaminated soil in Uppers Sillesia, Poland (Plaza et al., 2005), and it was used for petroleum bioremediation. Pseudomonas putida is a powerful phosphate solubilizer (Rodriguez et al. 1999) and was used for remediation of $\mathrm{Pb}$ 
contaminated shooting range soil (Wilson et al., 2006). The rock phosphate was obtained from Florida and North Carolina rock phosphate deposits. The biological phosphate (i.e., ground fish bones), called biogenic apatite in this paper, was obtained from Washington (PIMS NW, Inc. Richland, WA). Calcium and Na phytate was obtained from Dong Li Phytate Ltd., Anhui, China. Additionally, organoclay was tested for comparison as a weak U sorbent. Organoclays consist of bentonite that is modified with quaternary amines. Bentonite is a volcanic rock which main constituent is the clay mineral montmorillonite, which imparts an ion exchange capacity of 70-90 meq/gram. The bentonite becomes organically modified by exchanging the nitrogen end of a quaternary amine onto the surface of the clay platelets through cation exchange. For this study the organoclay was purchased from Biomin Inc., Ferndale, MI.

\subsection{Experimental procedures}

\subsubsection{Aqueous uranium removal}

The U removal by the phosphate amendments and microbes was evaluated in 50 $\mathrm{mL}$ centrifuge tubes for a period of one week. The amendments were tested individually and in mixtures. Each treatment had three replicates. The U concentration in the amended solution was $100 \mu \mathrm{g} \mathrm{L}^{-1} \mathrm{UO}_{2}{ }^{2+}$ (Inorganic Ventures, Lakewood, NJ). A suspension of 150 mg of solid (the sequestering agents), $1 \mathrm{ml}$ of microbes and $30 \mathrm{~mL}$ of spike solution was shaken for one week, phase separated by centrifugation, and the aqueous phase was analyzed for $\mathrm{pH}$ and U concentration by ICP-MS. Differences among treatments were analyzed by one-way analysis of variance (ANOVA) followed by the Holm-Sidak method (Systat Software, Inc., 2004) for testing differences between treatments. Data 
were $\log _{10}(\mathrm{X}+1)$ transformed prior to analysis to correct for non-normality and heteroscedasticity.

\subsubsection{Influence of phosphate amendments and microbial amendments on $U$ aqueous} concentrations

A series of laboratory experiments were conducted to evaluate the influence of four types of phosphate apatites (Florida rock phosphate, North Carolina rock phosphate, biological phosphate [ground fish bones], and calcium phytate) on U extractability. In these experiments two sediments were evaluated, one from Tims Branch (a second order stream on the Department of Energy's Savannah River Site - SRS near Aiken, South Carolina) and the other from Hanford (a major Department of Energy facility in Washington state). Tims Branch was contaminated with $\mathrm{U}$ and other metals (e.g., Ni, Al, $\mathrm{Cr}, \mathrm{Cu}, \mathrm{Cd}$ ) produced during fuel fabrication. Approximately $45000 \mathrm{~kg}$ of depleted $\mathrm{U}$ were released into Tims Branch from 1954 to 1985, with approximately 70\% still remaining in the sediments, primary as U(VI) (Evans et al., 1992; Bertsch et al., 1994). Hanford sediment was uncontaminated and was collected from Trench 8. It was included in this study to provide a measure of how uranium behaved in these treatments with a high carbonate-containing sediment. Because U concentrations were low in this sediment, 110 grams of Hanford sediment was spiked with $22 \mathrm{~mL}$ of 5 ppm U (Inorganic Ventures, Lakewood, NJ). The initial $\mathrm{pH}$ of the Hanford sediment was 8.94 but after spiking went down to about 7.13 and stayed fairly constant during two weeks of equilibration with the spike solution. The spiked, homogenized Hanford sediment was used to evaluate $\mathrm{U}$ mobility after mixing with amendments. In addition, a portion of this sediment was sterilized to determine if microbial activity affected $U$ extractability. Three grams of 
sediment were mixed individually with 0.150 grams (i.e., $5 \%$ by dry weight) of the following amendments: North Carolina apatite (NCA), calcium phytate (CaP), biological apatite (BA), sterilized NCA, sterilized CaP, and sterilized BA. Two replicates were analyzed for $\mathrm{U}$ and metals by ICP-MS, and the third replicate was used to measure $\mathrm{pH}$ values. The samples were extracted with water for one week, after which they were extracted with $12 \mathrm{~mL}$ of $1 \mathrm{M} \mathrm{MgCl}_{2}$ and analyzed for $\mathrm{U}$ and metals by ICP-MS. Differences among treatments were statistically tested as previously described for the $\mathrm{U}$ removal experiments. Evaluation of the effects of the amendments on the U extractability in Tims Branch sediment was conducted in the same manner as for the spiked Hanford sediment; however, the sterilization step was omitted.

\subsubsection{Synchrotron $X$-ray fluorescence mapping}

Microprobe Synchrotron X-ray Fluorescence (SXRF) measurements were made of the untreated Tim's Branch sediment at the National Synchrotron Light Source (NSLS), at the Brookhaven National Laboratory located in Upton, NY. The synchrotron hard X-ray fluorescence microprobe on the bending magnet at X26A of the NSLS was used with a channel-cut Si(110) monochromator. Microfocusing optics were used to produce the Xray beam (Eng et al. 1995). A double elliptical Au- or Rh-coated Kirkpatrick-Baez mirror system angled at 2 mrad was used to focus a 350- by 350- $\mu$ m monochromatic Xray beam $7 \mu \mathrm{m}$ vertical by $13 \mu \mathrm{m}$ horizontal beam (Eng et al. 1995). Milligram quantities of sediment were contained within fitted plastic inserts with polypropylene and kapton windows, placed in a metal frame and mounted on an automated, digital x-y-z stage at $45^{\circ}$ to the beam. Fluorescent X-rays were detected with a 9-element Ge Array detector (30 $\mathrm{mm}^{2}$ area; Canberra) mounted at $90^{\circ}$ to the incident beam and about $1 \mathrm{~cm}$ from the 
sample. Elemental mappings on the samples were conducted using micro-SXRF imaging at several areas, ranging from $100 \mu \mathrm{m}$ by $100 \mu \mathrm{m}$ to $300 \mu \mathrm{m}$ by $300 \mu \mathrm{m}$ in size. For elements with absorption energies below $18.5 \mathrm{keV}$, SXRF was performed by collecting $20 \mathrm{~s}$ live counts in the elemental regions of interest and rastering the sample in 4 to $5 \mu \mathrm{m}$ steps in the $\mathrm{x}-\mathrm{y}$ plane.

\section{Results and discussion}

\subsection{Effect of phosphate and microbial amendments on U removal}

All tested phosphate amendments reduced aqueous $U$ concentration more than 90\%, likely due to formation of insoluble phosphate precipitates (Figure 1). Ranking of the treatments by $U$ removal effectiveness was: calcium phytate $(\mathrm{CaP})>$ biological apatite (BA) $>$ North Carolina apatite (NCA) $>$ Florida apatite (FA) $>$ organoclay (OC) $>$ sodium phytate $(\mathrm{NaP})$. Differences among treatments were statistically significant $(\mathrm{F}=58.52$, $\mathrm{P}<0.001$ ), and $\mathrm{U}$ concentrations in all treatments except OC, $P$. putida, and NaP were significantly $(\mathrm{P} \leq 0.05)$ lower than in the spike. The addition of $A$. piechaudii and $P$. putida alone were found to reduce $\mathrm{U}$ concentrations by $63 \%$ and $31 \%$, respectively (Figure 1). However, these two microbes were less effective than phosphate for aqueous U removal. Also as expected, sodium phytate and organoclay were not good sorbents for U. When phosphate amendments were mixed with microbial treatments, U removal by phosphate was not enhanced (Figure 2). Instead, the distribution coefficients ( $\mathrm{K}_{\mathrm{d}}$ values) for $\mathrm{U}$ in phosphate treatments were substantially reduced in the presence of microbes (Figure 3). Uranium may react with apatite to form mineral phases of the autunite group, a diverse group of over 40 minerals, having the general formula: $\mathrm{M}\left(\mathrm{UO}_{2} \mathrm{PO}_{4}\right)_{2}-\mathrm{nH}_{2} \mathrm{O}$ 
(Bostick et al., 2000). Apatite minerals are known to react with many transition and heavy metals, metalloids, and radionuclides to rapidly form secondary phosphate precipitates that are stable over a wide range of geochemical conditions (Wright 1990, Wright et al., 1987, Ma et al., 1994, and Arey at al., 1999). Murray et al. (1983) have demonstrated the use of synthetic apatite for the retention of uranium and its daughter products from uranium mine leachates. Gauglitz et al. (1992) and later Jeanjean (1995) also demonstrated the removal of soluble $\mathrm{U}$ by crystalline apatite phase. Bostick et al. (2000) demonstrated that ground fish bone (biological apatite) is highly effective for the removal of soluble uranium from synthetic groundwater matrix, and that autunite (calcium uranyl phosphate) crystalline phase is formed at high loadings of uranium. Also, Wright et al. (1995) showed that biological apatite is very effective in U removal from aqueous phase. Arey et al. (1999) also showed that apatite additions lower aqueous U to near proposed drinking water standards in batch equilibrations of two distinct sediment strata having total U concentration of 1703 and $2100 \mathrm{mg} \mathrm{kg}^{-1}$, respectively. However, there are very limited data in the literature on the influence of microbes on the effectiveness of phosphate amendments. Most papers present data on the bioreduction of U or microbes that solubilize phosphate minerals to promote plant growth and yield. Our data showed that the effectiveness of phosphate in the presence of two tested microbes was reduced, as indicated by $\mathrm{K}_{\mathrm{d}}$ values (Figure 3). However, on the other hand, microorganism are very efficient biosorbents (Kurek et al., 1996), and therefore, the U concentration in our study in the presences of only microbes was reduce by 31 and $63 \%$, respectively by $P$. putida and A. piechaudii (Figure 1). 


\subsection{Influence of phosphate and microbial amendments on $U$ aqueous concentrations}

Addition of two phosphate amendments alone, North Carolina apatite and calcium phytate at $5 \mathrm{wt} \%$, significantly reduced water extractable U from Tim's Branch (TB) sediment (Figure 4). However, in treatments where TB sediment was treated with phosphate and microbial amendments (P. putida) U removal from the water soluble fraction was less or the same in the treatments where TB sediment was treated by phosphate amendments alone (Figure 4). Other researches, for example, Arey et al., (1999) also demonstrated that minor additions $\left(5 \mathrm{~g} \mathrm{~kg}^{-1}\right)$ of hydroxyapatite significantly reduced both the water-soluble and TCLP-extractable U. Thermodynamic calculations indicated that contaminant metal solubility was less than that of the pure metal phosphate (e.g., autunite for uranium), despite evidence that metal solubility was enhanced somewhat by the presence of soluble humics. Thus, understanding the processes controlling the formation of secondary phosphate precipitates is critical to predicting the long-term stability of the immobilized contaminant metal. In addition, phosphate is likely to reduce the solubility of trace metals associated within Fe oxides that dissolve under anoxic conditions.

Addition of phosphates increased the $\mathrm{pH}$ of TB sediment from 5.42 to 6.36 and 6.95, respectively, for North Carolina apatite and calcium phytate (Table 1). However, the $\mathrm{pH}$ of the TB sediment treated with bacteria decreased from 5.52 to 5.18, when compared to the control (i.e., untreated TB sediment) (Table 1). The decrease of sediment $\mathrm{pH}$ might be attributed to the secretion of proton, amino acid and organic acids through metabolic activities of bacteria (van der Lelie et al., 1999; Huang et al., 2002). On the other hand, the addition of bacteria to the phosphate treated TB sediment had no effect or 
only a slight effect on sediment $\mathrm{pH}$ (Table 1). Addition of phosphate alone released significant amount of $\mathrm{Ca}$ and $\mathrm{P}$ (Table 1). The P release was substantial, especially in the case of calcium phytate (Table 1). The microbial count in calcium phytate was the highest of all tested amendments (Figure 5). It seems that native microbes in calcium phytate contributed significantly to the dissolution of phosphate in the TB sediment. This fast release of phosphate permits rapid immobilization of $U$ and other contaminants if present. However, slower release, as expected from North Carolina apatite, could be beneficial for continued long term treatment. Several scientist have reported the ability of different bacterial species to solubilize insoluble phosphate compounds, such as tricalcium phosphate, dicalcium phosphate, hydroxyapatite, and rock phosphate. Wu et al. (2006) showed that B. megaterium significantly increased the available phosphate concentration in sediment. Addition of phosphate amendments also reduced Mn concentration in the water extracts from TB sediment from $50 \mathrm{mg} \mathrm{kg}^{-1}$ to almost zero (Table 1). However, in the treatments where the TB sediment was treated with P. putida, Mn concentration increased up to $250 \mathrm{mg} \mathrm{kg}^{-1}$. Such significant dissolution of Mn could cause release of $\mathrm{U}$ and other elements to the water solution since it is well know that many elements have high affinity for Mn mineral phases. The sychrotron X-ray fluorescence map of TB sediment (Figure 6) shows clearly that $U$ associated mostly with Mn, therefore, dissolution of Mn mineral phases in the presence of $P$. putida very likely also cause $\mathrm{U}$ dissolution, and this explains why aqueous $\mathrm{U}$ concentrations increased in TB sediments treated with $P$. putida (Figure 4). In TB sediment treated with phosphate, especially calcium phytate, substantial release of Fe was also observed (Figure 2). The release of Fe could reduce the ability of phosphate amendments to immobilize $U$ and 
other metals due to the strong affinity of Fe oxides for these elements (Figure 6).

Increased release of Fe or Mn was very likely related to higher native microbial population in calcium phytate (Figure 5). Therefore, the contribution of microorganisms to $\mathrm{U}$ removal was examined by testing $\mathrm{P}$ amendments with their natural populations and autoclaved amendments (sterilized i.e., without microbial populations). The effects of sterilization of amendments on $\mathrm{U}$ mobility were evaluated by water extraction and $1 M$ $\mathrm{MgCl}_{2}$ extraction.

ANOVA showed that sterilization of amendments had a statistically significant effect on $\mathrm{U}$ mobility ( $\mathrm{F}=284.16, \mathrm{P}<0.001)$ (Figures 7 and 8). The $\mathrm{U}$ concentration in $1 M$ $\mathrm{MgCl}_{2}$ extract from the $\mathrm{U}$ spiked Hanford sediment was $437 \mu \mathrm{g} / \mathrm{kg}$, but in the same sediment without microbes (autoclaved), the U concentration was only $103 \mu \mathrm{g} / \mathrm{kg}$ ( $\mathrm{P} \leq 0.05$, Holm-Sidak test) (Figure 8). In amended Hanford sediment that was sterilized by autoclaving and treated with sterilized biological apatite, $\mathrm{U}$ concentration in the $1 \mathrm{M}$ $\mathrm{MgCl}_{2}$ extract was zero compared with $74 \mu \mathrm{g} / \mathrm{kg}$ in unsterilized sediment that was treated with biological apatite ( $\mathrm{P} \leq 0.05$, Holm-Sidak test). These comparisons strongly suggest that microbes enhance U mobility (Figure 8).

Bacteria may enhance the mobility of heavy metals or radionuclides, e.g., they increase the water soluble or $\mathrm{MgCl}_{2}$ soluble fraction by dissolution and desorption from the secretion of proton and various ligands. Generally, in the presence of bacteria, the sediment $\mathrm{pH}$ decreases and dissolved organic carbon increases. Thus, more metals could be transformed to the higher mobile fractions (Wu et al., 2006). On the other hand, bacteria could adsorb, immobilize and complex metals and radionuclides via surface interaction and secretion of chelating agents, which results in metals transformation to 
more stable forms. For example, Wu et al. (2006) showed that water-soluble Zn was significantly increased in the presence of bacteria. Also, Huang et al. (2002) reported that inoculation of rhizobia increased water-soluble Zn and DTPA exchangeable Zn in sediment. However, other researches; Berthelin et al., 1990 and Kurek and Majewska (2004) reported high Cd sorption capacity of fungi live biomass and low remobilization of immobilized Cd. The studies indicated that decreased content of the most mobile Cd fraction (extracted by $0.1 \mathrm{M} \mathrm{NaNO}_{3}$ ) in sediment supplemented with $\mathrm{Cd}$ immobilized by Trichoderma koningii biomass after a 42-day incubation was connected with a transfer of this element from this operational fraction to the most stable residual fraction. However, the role of bacteria in phosphate remediation technology needs to be carefully evaluated; considerable attention should be paid to the increasing downward movement of $U$ and other elements induced by bacterial inoculation, in order to prevent any secondary pollution to groundwater or ambient regions.

\section{Conclusions}

Radionuclides that contaminate soils/sediments cannot be destroyed, but their toxicity can be diminished through alteration of their chemical speciation. Ideally, such chemical alterations (e.g., reduction or precipitation) will convert toxic and mobile species to nontoxic and immobile species. The use of sequestering agents to remediate contaminated sediments offers considerable potential for long-term environmental cleanup. The potential effects of microbial organisms on amendment effectiveness require further investigation. 
This paper presents new useful data on interactions among phosphate amendments, microbes, and uranium mobility in contaminated sediments. The results could lead to improved technologies and approaches for the long-term environmental remediation challenges posed by metal contaminated sediments. This data also could have beneficial applications to other technologies such as tank closure, concrete immobilization, and aqueous removal.

\section{Acknowledgements}

This research was supported by the FY 2005 SRNL Independent Research \& Development Program and Strategic Environmental Research and Development Program (Project ER-1501). The authors thank Martine Duff from Savannah River national Laboratory (SRNL) for conducting the Synchrotron X-ray Fluorescence measurements. Additionally, the manuscript preparation was supported by the SRNL's Mini-Sabbatical Program. Performers of this project would like to thank to all commercial companies for supplying sequestering agents.

\section{References}

Arey JS, Seaman JC, Bertsch PM. Immobilization of uranium in contaminated sediments by hydroxyapatite addition. Environ Sci Technol 1999;33:337-42.

Berthelin J, Guillek B, Rouiller J, Sadio S, Gueniooot B, Munier-Lamy C. A bag method to study the release, exchange, fixation and preconcentration of elements from sediment minerals. In: Harrison A, editor. Nutrient cycling in terrestrial 
ecosystems. Field methods, application and interpretation. London: Elsevier; 1990. p.23-35.

Bertsch PM, Hunter DB, Sutton DB, Bajt S, Rivers ML. In situ chemical speciation of uranium in soils and sediments by microX-ray absorption spectroscopy. Environ Sci technol 1994; 28:980-84.

Bostick WD, Stevenson RJ, Jarabek RJ, Conca JL, Use of apatite and bone char for the removal of soluble radionuclides in authentic and simulated DOE groundwater. Advances in Environ Research 2000; 3(4):488-98.

Eng, P. J.; Rivers, M. L.; Yang, B. X.; Schildkamp, W. Microfocusing 4-keV to 65-keV X-rays with bent Kirkpatrick-Baez mirrors. Proc. SPIE 1995; 2516:41-51.

Evans AG, Bauer LR, Haslow JS, Hayes DW, Martin HL, McDowell WL, Pickett JB. Tech. Rep. WSRC-RP-92-315. Aiken: Westinghouse Savannah River Company; 1992.

Gauglitz R, Holterdorf M, Frank W, Marx G. Immobilization of actinides by hydroxyapatite. Mat Res Symp Proc 1992;257:567-73.

Huang QY, Chen WL, Guo XJ. Sequential fractionation of $\mathrm{Cu}, \mathrm{Zn}$ and $\mathrm{Cd}$ in soils in the absence and presence of rhizobia. Proceedings of $17^{\text {th }}$ WCSS 2002. Thailand; 2002. p. 1453.

Internet: PIMS NW, Inc. Richland, WA (www.pimsnw.com).

Jeanjean J, Rouchard JC. Sorption of uranium and other heavy metals on hydroxyapatite. J Radioanalyt Nucl Chem-Letters 1995;201(6):529. 
Jensen, MP, Nash KL, Morss LR, Appelman EH, and. Schmidt MA. Immobilization of actinides in geomedia by phosphate precipitation. Humic and fulvic acids: Isolation, structure and environmental role. ACS Symp. Ser. 1996;651:272-285.

Knox AS, Seaman J, Mench MJ, Vangronsveld J. Remediation of metal- and radionuclide- contaminated soils by in situ stabilization techniques. In: Iskandar IK, editor. Environmental Restoration of Metals-Contaminated Soils, Boca Raton: CRC Press; 2000a. p. 21-60.

Knox AS, Seaman J, Pierzynski G. Chemo-phytostabilization of metals in contaminated soils. In: Wise DL et al., editors. Remediation of Hazardous Waste Contaminated Soils, 2 nd Edition, New York: Marcel Dekker, Inc.; 2000b. p. 811-36.

Knox AS, Kaplan DI, Adriano DC, Hinton TG, Wilson MD. Apatite and phillipsite as sequestering agents for metals and radionuclides. J Environ Qual 2003;32:515525.

Knox AS, Kaplan DI, Hang T. Phosphate mineral sources evaluation and zone-ofinfluence estimates for soil contaminant amendments at the T-Area Outfall Delta (U). Tech. Rep. WSRC-TR-2003-00579, Rev. 0. Westinghouse Savannah River Company, Aiken; 2004.

Knox AS, Kaplan DI, Paller MH. Phosphate sources and their suitability for remediation of contaminated soils. Sci Total Environ 2006;357:271-79.

Kurek E, Kaczorowska R, Nadulska I, Ochal M, Puach E, Patkowska E. Retention of Cd by soil constituents under different environmental conditions. Chemisphere 1996;33:277. 
Kurek E, Majewska M. In vitro remobilization of Cd immobilized by fungal biomas. Geoderma 2004;122:235-

Ma QY, Logan TJ, Traina SJ, Ryan JA. Effects of $\mathrm{NO}_{3}{ }^{-}, \mathrm{Cl}^{-}, \mathrm{F}^{-}, \mathrm{SO}_{4}{ }^{2-}$, and $\mathrm{CO}_{3}{ }^{2-}$ on $\mathrm{Pb}^{2+}$ immobilization by hydroxyapatite. Environ Sci Technol 1994a;28:408-418.

Ma QY, Traina SJ, Logan TJ, Ryan JA. Effects of aqueous Al, Cd, Cu, Fe(II), Ni, and Zn on Pb immobilization by hydroxyapatite. Environ Sci Technol 1994b;28:12191228.

Ma LQ, Logan TJ, Traina SJ. Lead immobilization from aqueous solutions and contaminated sediments using phosphate rocks. Environ Sci Technol 1995;29:1118-1126.

Ma LQ, Rao GN. The effect of phosphate rock on Pb distribution in contaminated soils. J Environ Qual 1997;26:259-64.

Nash KL, Jensen MP, Hines JJ, Freidrich SA, Redko M. Phosphate mineralization of actinides by measured addition of precipitating anions. Tech. Rep.TTP\# CH2-6C3-22, Argonne National Laboratory, Argonne; 1997.

Nash KL, Jensen MP, Schmidt MA. Actinide immobilization in the subsurface environment by in-situ treatment with a hydrolytically unstable organophosphorus complexant: Uranyl uptake by calcium phytate. J Alloys and Compounds 1998a;271-273: 257-261.

Nash KL, Jensen MP, Schmidt MA. In-situ mineralization of actinides of groundwater cleanup: Laboratory demonstration with soil from the Fernald Environmental Management Project. In: Schultz WW, Lombardo NJ, editors. Science and 
technology for disposal of radioactive tank waste. New York: Plenum Press; 1998b. p. 507-18.

Plaza GA, Ulfig K, Brigmon RL. Surface active properties of bacterial strains isolated from petroleum hydrocarbon-bioremediated soil. Pol J Microbiol 2005;54(2):16167.

Rodriguez H., Fraga R. Phosphate solubilizing bacteria and their role in plant growth promotion. Biotechnology Advances 1999;17:319-39.

Ryan JA, Zhang P, Hesterberg D, Chou L, Sayers DE. Formation of chloropyromorphite in a lead-contaminated sediment amended with hydroxyapatite. Environ Sci Technol 2001;35:3798-3803.

Seaman JC, Meehan T, Bertsch PM. Immobilization of cesium-137 and uranium in contaminated sediments using sediment amendments. J Environ Qual 2001;30:1206-1213.

Singh SP, Ma LQ, Harris WG. Heavy metal interactions with phosphatic clays: Sorption and desorption behavior. J Environ Qual 2001;30:1961-1968.

Systat Software, Inc. SigmaStat 3.1. Systat Software, Inc., Point Richmond, CA, 2004.

Van der Lelie D, Corbisier P, Diels L, Gilis A, Lodewyckx C, mergeay M, Taghavi S, Spelmans N, Vangronsveld J. The role of bacteria in the phytoremediation of heavy metals. In: Terry N, Banuelos GS, editors. Phytoremediation of contaminated soil and water. Boca Raton, FL: CRC Press; 1999. p. 265-81.

Wilson C, Brigmon RL, Knox AS, Seaman J, Smith G. Effects of microbial and phosphate amendments on the bioavailability of lead $(\mathrm{Pb})$ in shooting range soil. Bull Environ Contam Toxicol 2006;76:392-99. 
Wise A. Influence of calcium on trace metal interactions with phytate. In: Graf E, editor. Phytic acid: Chemistry and applications. Minneapolis: Pilatus Press; 1986. p. 15160.

Wright J. Condont apatite: structure and geochemistry. In: Carter J, editor. Metazoan biomineralization: patterns, processes and evolutionary trends. New York: Van Nostrand Reinhold; 1990. p. 445-459.

Wright JV, Peurrung LM, Moody TE, Conca JL, Chen X, Didzerekis PP, Wyse E. In Situ Immobilization of Heavy Metals: Apatite Mineral Formations. Technical Report to the Strategic Environmental Research and Development Program, Department of Defense, Pacific Northwest National Laboratory, Richland; 1995. 154pp.

Wu SC, Luo YM, Cheung KC, Wong MH. Influence of bacteria on Pb and Zn speciation, mobility and bioavailability in soil: A laboratory study. Environ Pollut 2006;144:765-73. 
Table 1. Effect of phosphate and microbial treatments on TB sediment $\mathrm{pH}$ and $\mathrm{Ca}, \mathrm{Fe}$, Mn, and P concentration in water solution; TB - Tims Branch sediment, NCA - North Crolina apatite, $\mathrm{CaP}$ - calcium phytate, $\mathrm{M}$ - P. putida.

\begin{tabular}{|c|c|c|c|c|c|c|c|c|c|c|}
\hline \multirow[t]{2}{*}{ Treá } & \multicolumn{2}{|c|}{$\mathrm{Ca}$} & \multicolumn{2}{|c|}{$\mathrm{Fe}$} & \multicolumn{2}{|c|}{ Mn } & \multicolumn{2}{|c|}{$\mathrm{P}$} & \multicolumn{2}{|c|}{$\mathrm{pH}$} \\
\hline & Avg & Stdev & Avg & Stdev & Avg & Stdev & Avg & Stdev & Avg & Stdev \\
\hline TB & 0.78 & 0. & 02 & 0 & 0 & & 0.1 & 0.1 & 2 & 0.14 \\
\hline TB/ & 40.87 & & 0 & 100 & 0.010 & & 0.1 & 0.03 & 0.36 & 0 \\
\hline TB/ & 3.41 & 2.14 & 0.184 & 4 & 0.0 & 0.00 & 55.93 & .87 & 6.95 & .06 \\
\hline $\mathrm{TB} / \mathrm{N}$ & 1.72 & 40 & 0.014 & 0.00 & 0.083 & 0.09 & 0.40 & 0.06 & 6.22 & 0.03 \\
\hline TB/CaP & 71.31 & 2.99 & 0.079 & 0.03 & 0.018 & 0.00 & 34.65 & 2.33 & 6.99 & 0.02 \\
\hline $\mathrm{TB} / \mathrm{M}$ & 5.40 & 1.12 & 0.026 & 0.01 & 2.517 & 0.11 & 0.06 & 0.02 & 5.18 & 0.05 \\
\hline
\end{tabular}




\section{LIST OF FIGURES}

Figure 1. Removal of aqueous U by phosphate treatments and microbes; FA - Florida apatite, NCA - North Crolina apatite, BA - biological apatite, CaP - calcium phytate, NaP - sodium phytate, M1 - A. piechaudii, M2 - P. putida, and OC - organoclay.

Figure 2. Effect of microbial treatment on phosphate amendments effectiveness; FA Florida apatite, BA - biological apatite, $\mathrm{CaP}$ - calcium phytate, $\mathrm{M} 1$ - A. piechaudii, $\mathrm{M} 2$ P. putida

Figure 3. Effect of microbes on Kd values; M1 - A. piechaudii, M2 - P. putida.

Figure 4. Effect of phosphate and microbes amendments on U desorption from Tims Branch sediment, TB - Tims Branch sediment, NCA - North Carolina apatite, CaP calcium phytate, $\mathrm{M}-P$. putida (U concentration in ug/L in water extract).

Figure 5. Microbial activity in Tims Branch sediment and in the treated sediment with phosphate and microbial amendments.

Figure 6. U association with $\mathrm{Mn}$ and Fe.

Figure 7. Effect of phosphate amendments and sterilization of amendments on $U$ mobility; $1 \mathrm{M} \mathrm{MgCl} 2$ extraction, the following acronyms stand for: HS - U spiked Hanford sediment, NCA - North Carolina 
Apatite, NCAs - sterilized North Carolina Apatite, CaP - calcium phytate, CaPs sterilized calcium phytate, BA - biological apatite (ground fish bones), Bas - sterilized biological apatite, sediment/amendment/liquid ratio: 3g/0.15g/20 mL

Figure 8. Effect of sterilization of sediment and biological apatite on U mobility following $1 \mathrm{M} \mathrm{MgCl}_{2}$ extraction; HS - U spike Hanford sediment, SHS - sterilized U spiked Hanford sediment, BA - biological apatite (ground fish bones), BAs - sterilized biological apatite, sediment/amendment/liquid ratio: 3g/0.15g/20 mL. 


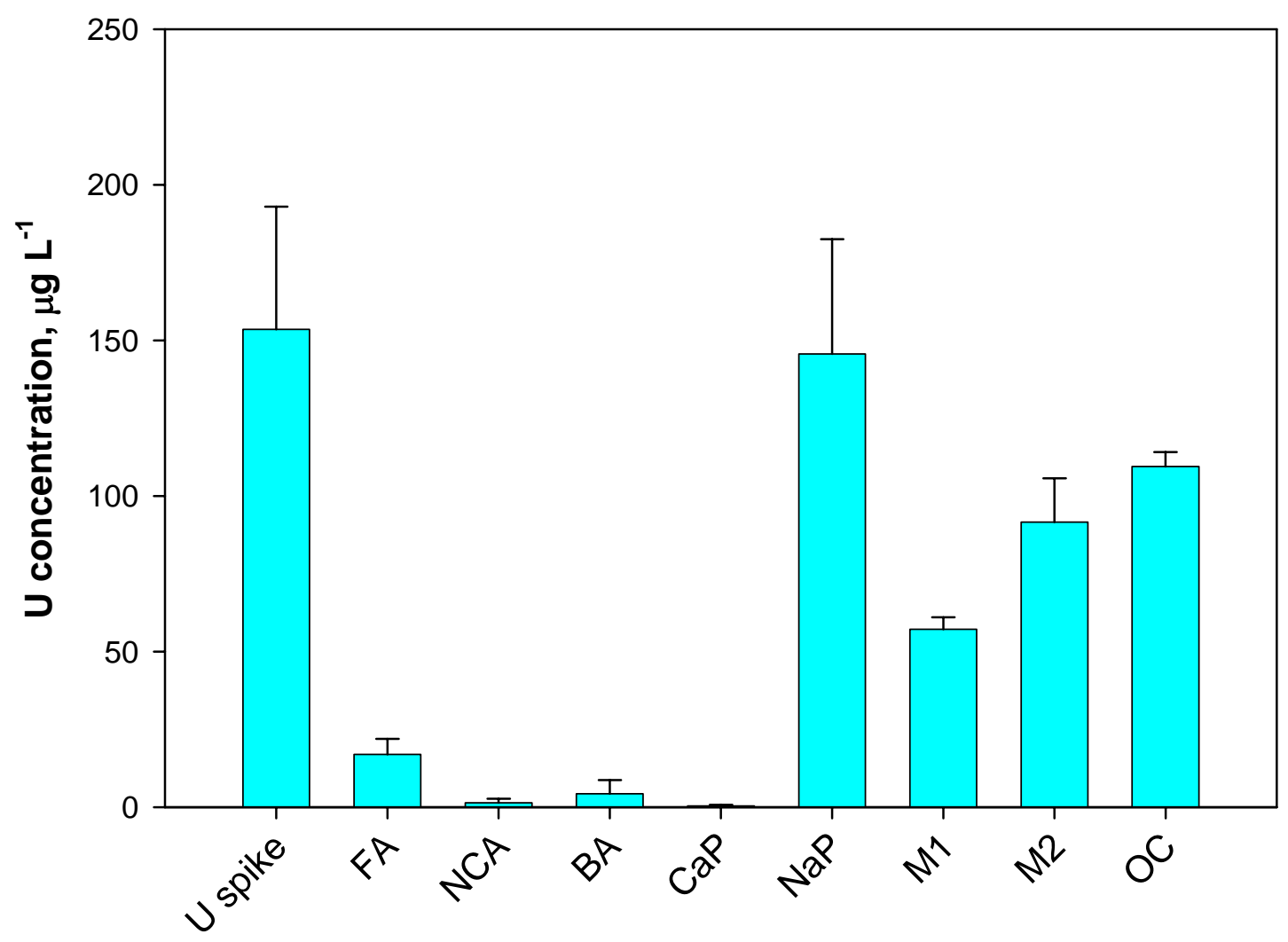

Treatments 


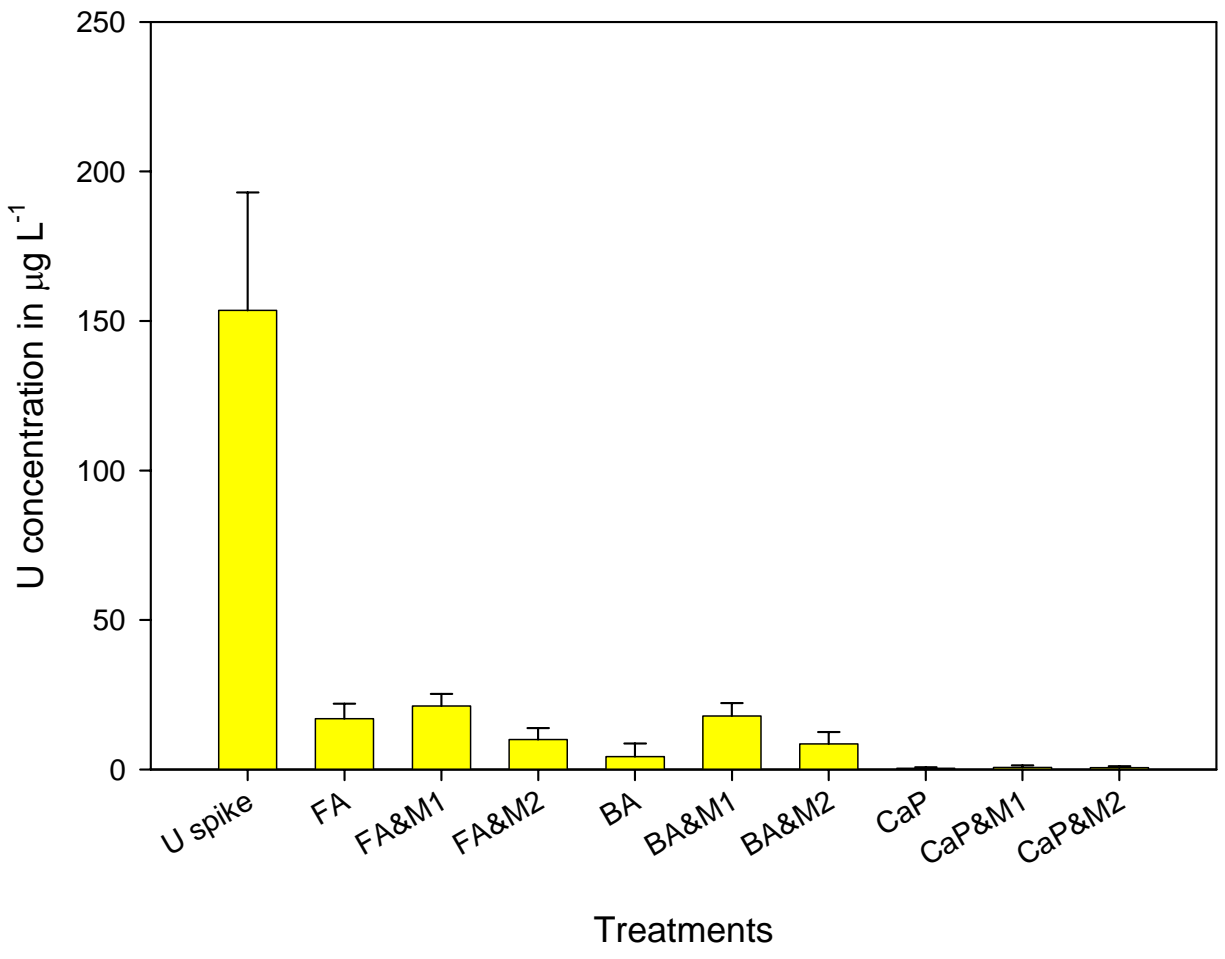




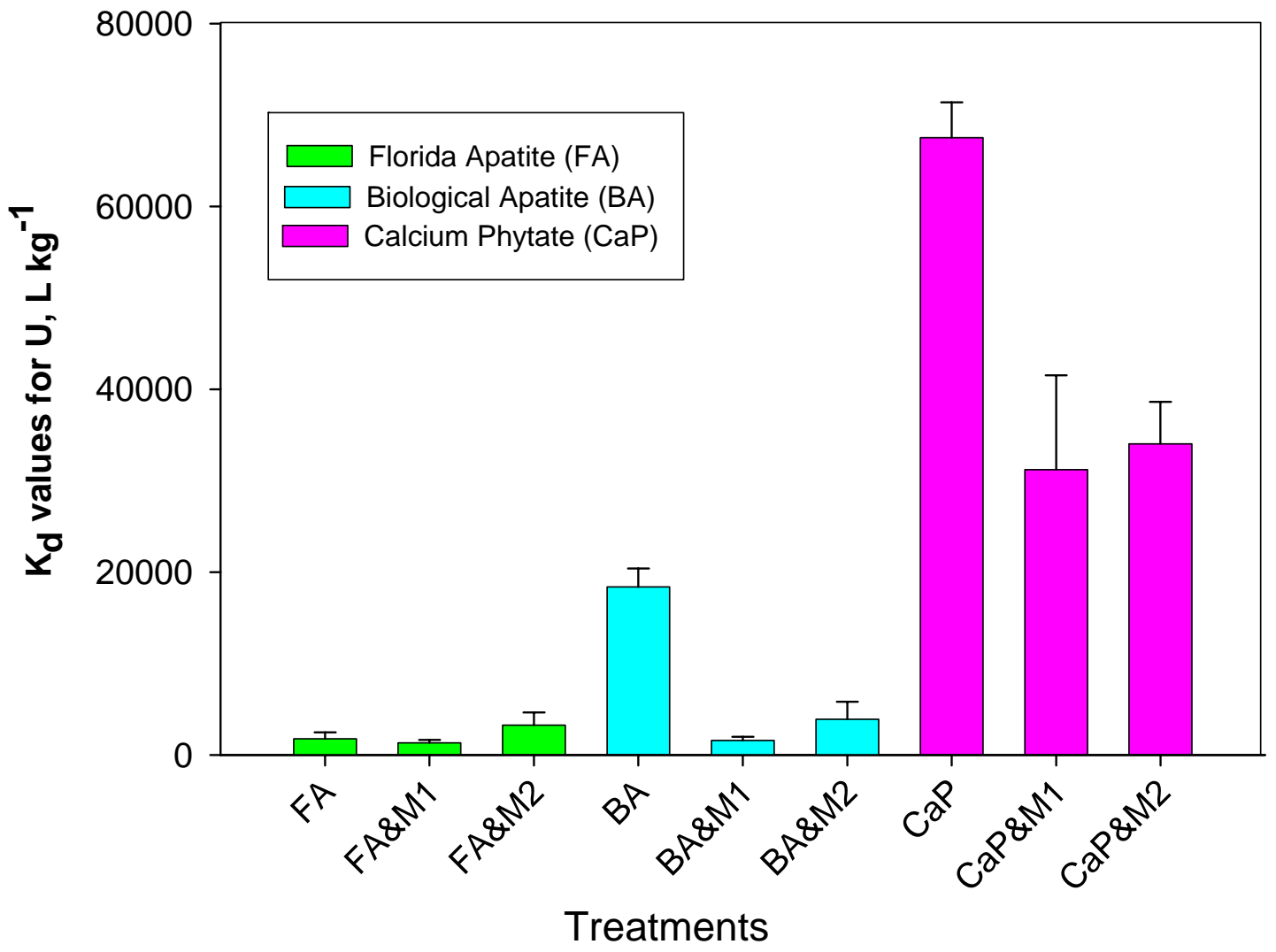




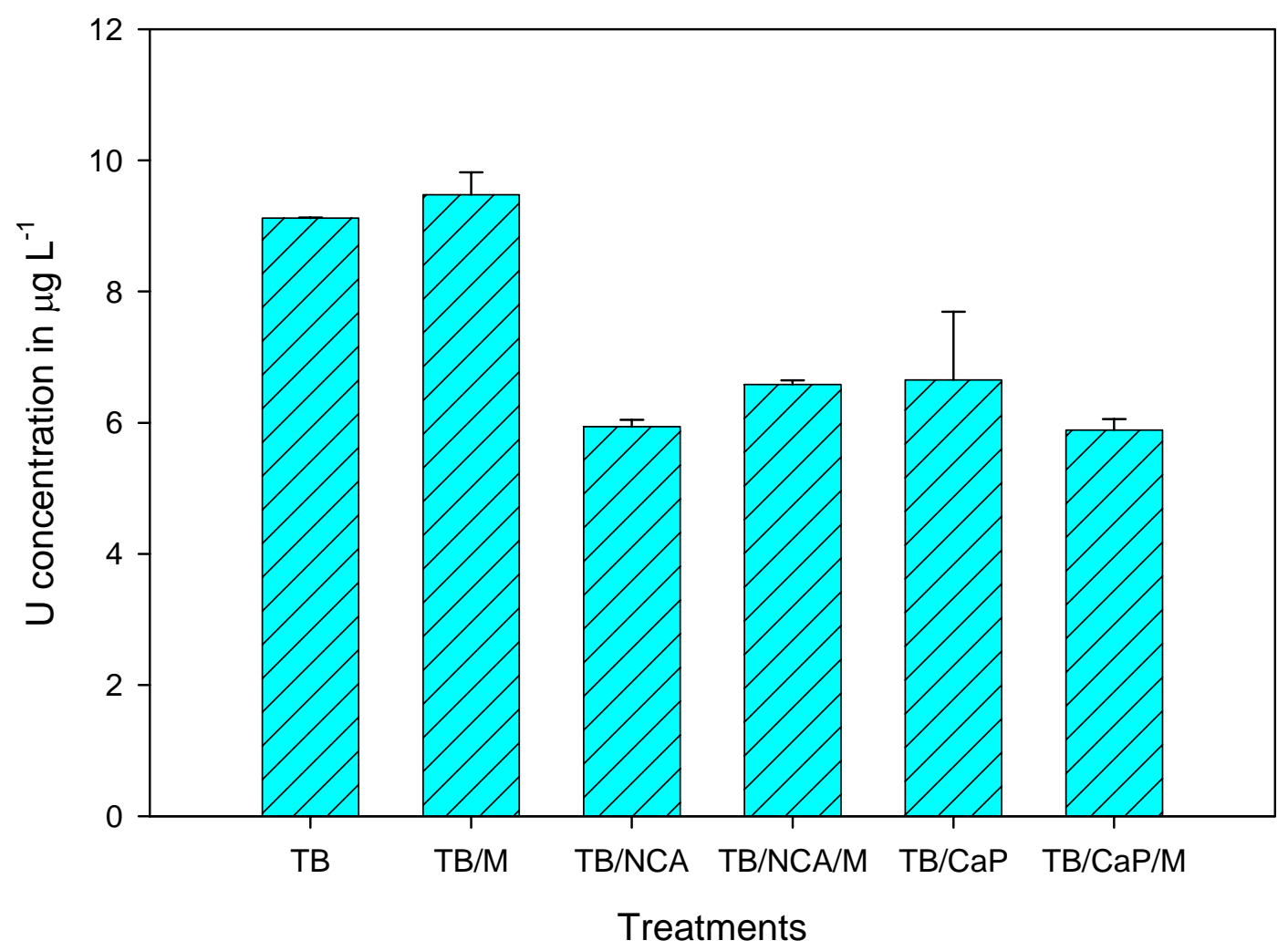




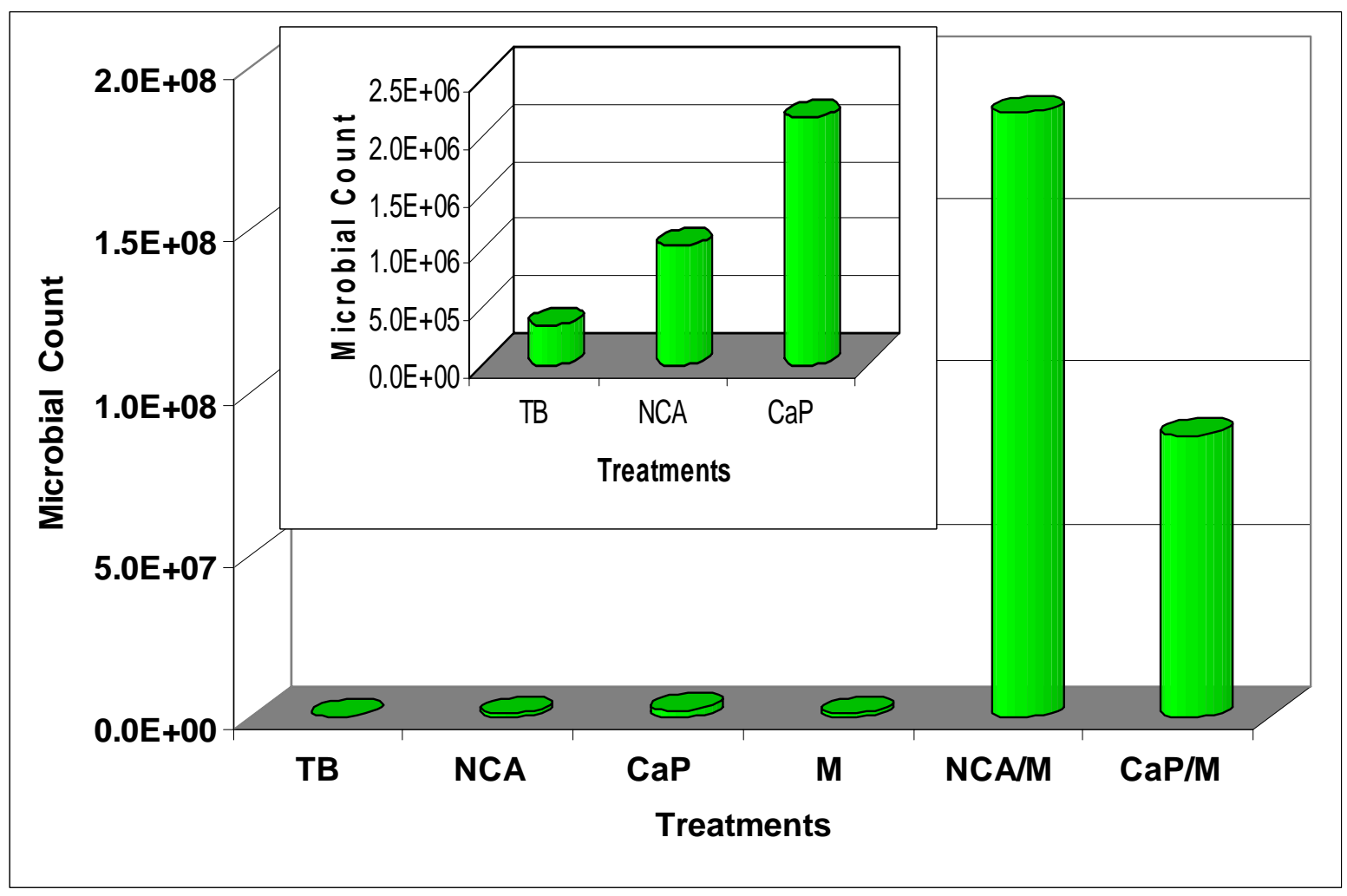




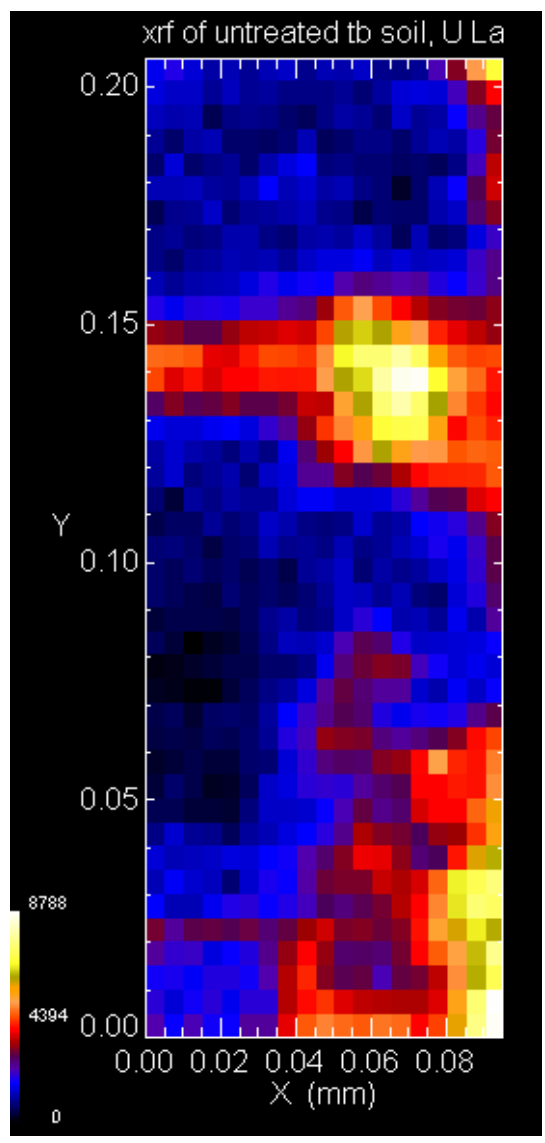

U

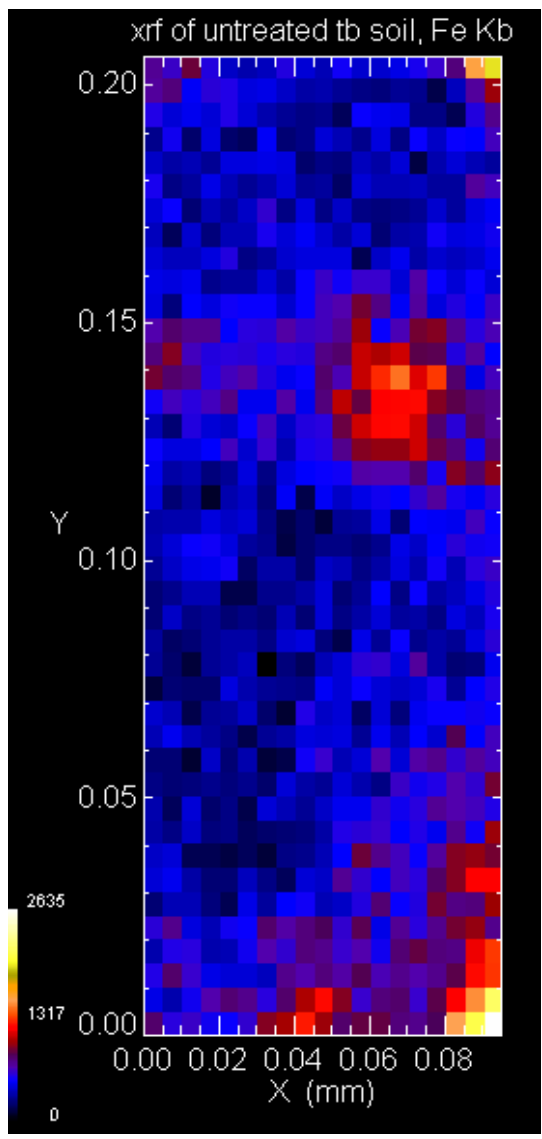

Fe

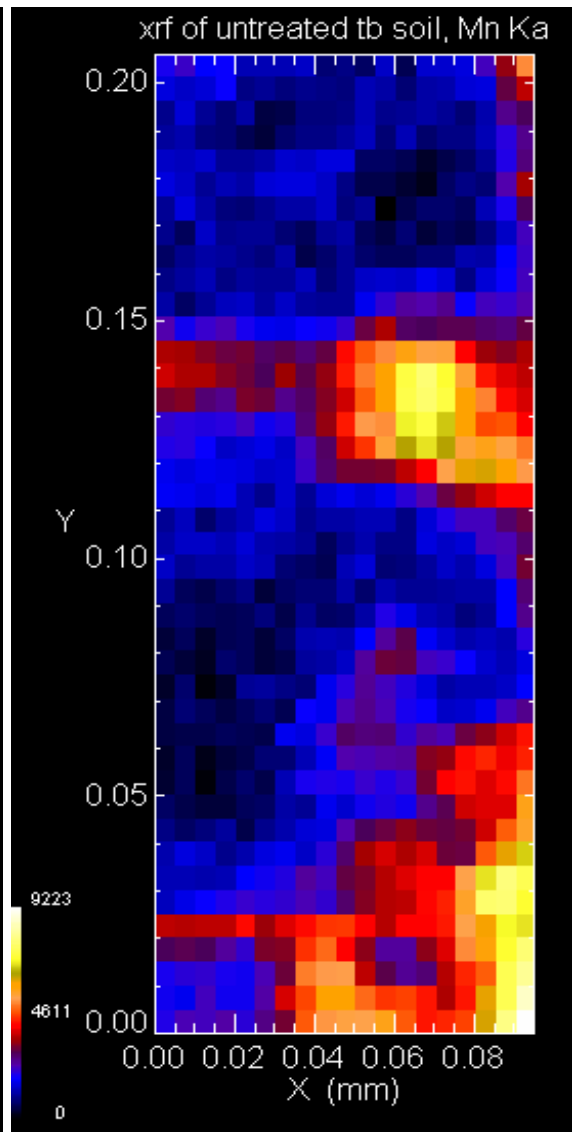

Mn 


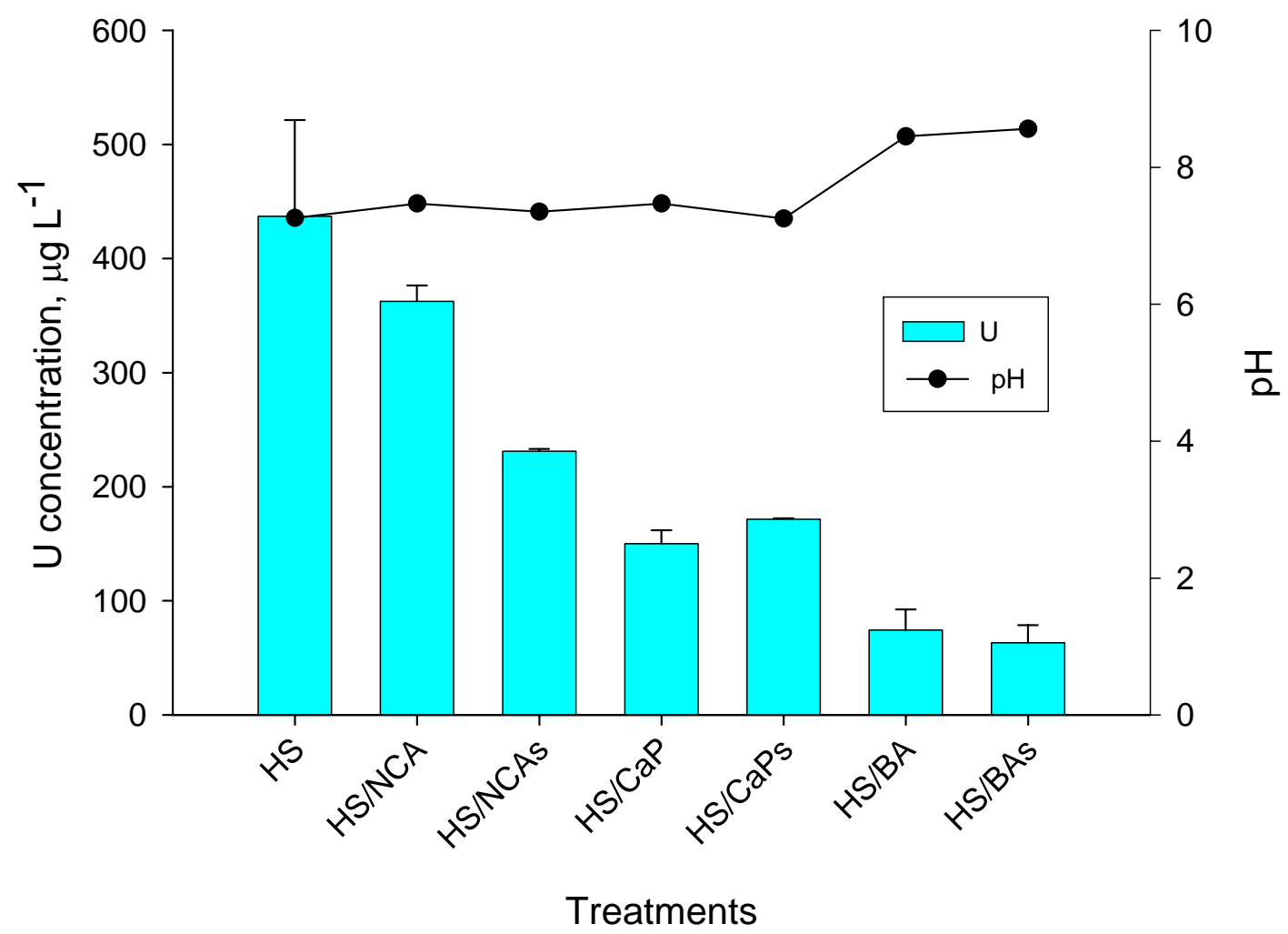




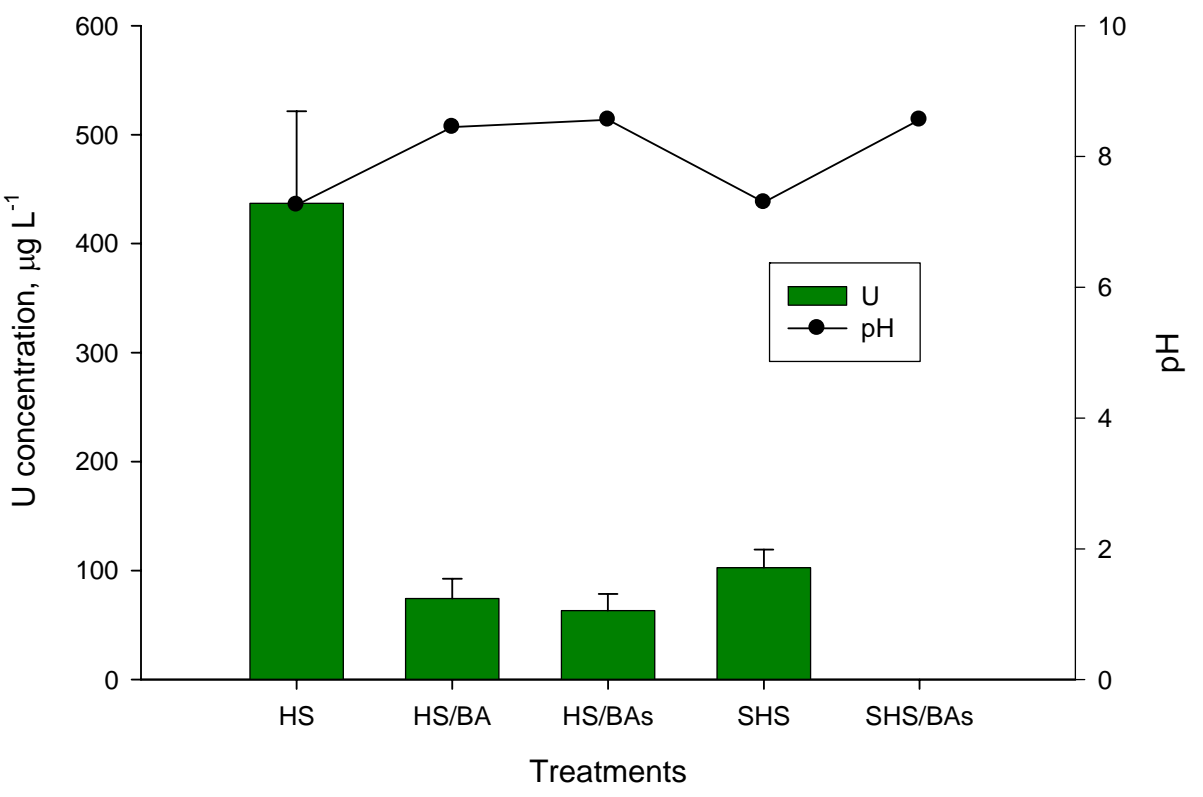

